\title{
Optimal administration of bronchodilators with valved holding chambers in preschool children: a review of literature
}

\author{
Péter Csonka ${ }^{1,2}$ (1) $\cdot$ Terhi Tapiainen $^{3} \cdot$ Mika J. Mäkelä $^{4}$ - Lauri Lehtimäki ${ }^{5,6}$ \\ Received: 18 January 2021 / Revised: 6 March 2021 / Accepted: 8 April 2021 / Published online: 20 April 2021 \\ (C) The Author(s) 2021
}

\begin{abstract}
Our aim was to synthesize the published literature on factors that potentially affect the delivery of bronchodilators using valved holding chambers (VHC) in preschool children. We also aimed to identify those attributes that are not yet incorporated or clearly stated in the guidelines and those topics that are still lacking sufficient data. There is strong evidence supporting several recommendations in current guidelines. Based on present knowledge, bronchodilators should be delivered by VHC administering each puff separately. Face mask should be omitted as soon as the child can hold the mouthpiece of the VHC tightly between the lips and teeth. Based on the review, we suggest adding a specific note to current guidelines about the effect of chamber volume and the impact of co-operation during drug administration. Calming the child and securing a tight face-to-mask seal is critical for successful drug delivery. There is not enough evidence to make specific recommendations on the most reliable VHC and face mask for children. There is an urgent need for studies that evaluate and compare the effectiveness of VHCs in various clinical settings in wide age-groups and respiratory patterns. In addition, there is insufficient data on ideal chamber volume, material, and effective antistatic treatment.
\end{abstract}

What is Known:

- Valved holding chambers (VHC) should not be considered interchangeable when used with pressurized metered dose inhalers (pMDI).

- Drug delivery is influenced by VHC volume, aerodynamic and electrostatic properties; mask fit; respiratory pattern and co-operation during inhalation; and the number of puffs actuated.

What is New:

- The impact of co-operation, VHC volume, and good mask-to-face fit during drug inhalation is not stressed enough in the guidelines.

- Studies are urgently needed to evaluate the effectiveness of different VHCs in various clinical settings focusing on VHC electrostatic properties, respiratory patters, face masks, and ideal pMDI+VHC combinations.

Keywords Bronchodilators · Valved holding chambers · Preschool children · Spacer · Acute · Management · Asthma . Wheezing $\cdot$ Emergency treatment $\cdot$ Inhalation therapy $\cdot$ Guidelines $\cdot$ Drug delivery

Communicated by Peter de Winter

Péter Csonka

peter.csonka@terveystalo.com

Terhi Tapiainen

terhi.tapiainen@oulu.fi

Mika J. Mäkelä

mika.makela@hus.fi

Lauri Lehtimäki

lauri.lehtimaki@tuni.fi

1 Centre for Child Health Research, Tampere University and Tampere University Hospital, Kalevantie 4, 33014 Tampereen yliopisto, Tampere, Finland
2 Terveystalo Healthcare, Tampere, Finland

3 Department of Pediatrics and Adolescent Medicine, Oulu University Hospital and PEDEGO Research Unit, University of Oulu, Oulu, Finland

$4 \quad$ Skin and Allergy Hospital, Helsinki University Hospital and University of Helsinki, Helsinki, Finland

5 Allergy Centre, Tampere University Hospital, Tampere, Finland

6 Faculty of Medicine and Health Technology, Tampere University, Tampere, Finland 


\section{Introduction}

Acute bronchoconstriction and viral wheezing account for approximately $10 \%$ of the emergency room (ER) visits in children resulting in hospitalization in $30-50 \%$ of cases $[1,2]$. Bronchodilators administered by pressurized metered dose inhalers (pMDI) via valved holding chambers (VHC) are clinically at least as effective as nebulizers [2-7]. Although most current guidelines recommend the use of VHC for the delivery of bronchodilators in acute bronchial obstruction in young children [8-14], nebulizers are still widely used. In the era of coronavirus disease 2019 (COVID-19) pandemic, there is considerable concern about the potential risk of transmission the virus in the form of aerosolized respiratory droplets by nebulizers $[15,16]$, although preschool children are not the main spreaders of COVID-19. Consequently, the use of metered-dose inhalers (MDIs) have increased considerably as an alternative to nebulized therapy.

In clinical practice, the most reliable and effective VHC delivery system - with and without face masks - and optimal dosing regimen of bronchodilators should be used. However, each VHC has its own unique features related to material, electrostatic and aerodynamic properties, volume, dead space, and valve design. Furthermore, the face mask fit and crying during inhalation administration may affect the treatment efficacy.

Our aim was to synthesize the published literature on factors that potentially affect the delivery of bronchodilators using valved holding chambers (VHC) in preschool children. We also aimed to identify those attributes with sufficient evidence that are not yet incorporated or clearly stated in the guidelines, and those topics that are still lacking sufficient data.

\section{Review of the literature}

We searched the following electronic databases up to October 25, 2020, to capture systematic reviews and individual trials: Medline (OVID), US National Library of Medicine PubMed, Cochrane Database of Systematic Reviews, Duodecim Terveysportti database in Finland, Google Scholar, and Google internet search engine. The following search terms were used: nebulizer, nebuliser, spacer or valved holding chamber in combination with any of the following: antistatic, static, washing, priming, mask, face mask, facemask, seal, fit, wheezing, asthma, salbutamol, albuterol, bronchodilator, beta-sympathomimetic(s) number of puffs, guideline, and review. The search was limited to English and Finnish language publications. In addition to searching the electronic databases, we screened the reference lists from the already identified studies, review articles, and guidelines for any additional studies. There were 3221 records with abstract identified. After the duplicates were removed, 3092 records were screened, and 2928 records were excluded. Altogether 124 full-text articles were assessed for eligibility, and 66 fulltext articles were excluded. Finally, 58 studies were included in the synthesis.

\section{Delivered dose of bronchodilators with different types of VHC}

Each VHC has its own unique features related to material, electrostatic and aerodynamic characteristics, volume, dead space, and valve design [17-21] (Table 1). Thus, certain combinations of pMDI+VHC may result in marked differences in dose output [18, 19, 21-27]. For example, using tidal volume Vt $50 \mathrm{ml}$ and RR 30/min Mitchell et al. [24] found that one of the three VHCs investigated (Space Chamber, Vent-170 and Child AeroChamber) yielded undetectable levels of salbutamol compared to $37 \mu \mathrm{g}$ filter dose from another device. A recent study observed markedly better salbutamol delivery with Optiochamber Diamond compared to Babyhaler especially with Vt below $150 \mathrm{~mL}$ [28]. In addition, similar devices from different brands may have up to 20-fold differences in drug delivery capacity in experimental in vitro models [17, 20].

The review of the literature showed that VHCs are not interchangeable and recommended drug doses may have to be adjusted according to the properties of each pMDI+VHC combination. However, there is insufficient evidence regarding the clinically most effective VHC. This is reflected in the current lack of standardization and variations in the use of these devices. There are no specific recommendations in the guidelines about VHC models (Table 2).

\section{Impact of VHC volume on the output of bronchodilators}

In children, larger volume VHCs $(>200 \mathrm{~mL})$ may result in a lower salbutamol output compared with smaller VHCs $(<200$ $\mathrm{mL})[17,22,27,29]$. In large volume VHCs, the aerosol concentration and particle impaction are less than in a smaller volume VHC. This can result in lower inhaled doses at a decreased Vt but higher doses when the VHC can be emptied faster with a larger Vt [29-33]. During bronchoconstriction, $\mathrm{Vt}$ decreases and RR increases, and asthmatic patients have a higher range of variation in PIFR compared to healthy subjects [34]. Operation of VHCs under suboptimal conditions is clinically important since children below school age can have inspiratory flow rates as low as $2 \mathrm{~L} / \mathrm{min}$ [34]. Only the GINA guidelines [9] indicate that using spacers with less than $350-\mathrm{mL}$ chamber volume is advantageous in very young children (Table 2). 
Table 1 Characteristics of some valved holding chambers (VHC) on the market worldwide. Each device has its own range of face masks. Disposable cardboard VHCs are not compatible with any mask. Face masks vary considerably in volume $(40-100 \mathrm{ml})$, softness and fit. DispoZABLE spacer has no valve (not a VHC) but is marketed also for children

\section{VHC Chamber material \\ volume and static charge specified by the manufacturer*}

\begin{tabular}{|c|c|c|c|}
\hline A2A Spacer (A2A) & $210 \mathrm{~mL}$ & ABS, antistatic & $\begin{array}{l}\text { Internal circular unidirectional silicon valve, aerosol passes through the } \\
\text { valve centrally }\end{array}$ \\
\hline Aerochamber plus & $149 \mathrm{~mL}$ & ABS, antistatic & $\begin{array}{l}\text { Internal circular unidirectional silicon valve, aerosol passes at the valve } \\
\text { periphery, top outside inspiratory indicator }\end{array}$ \\
\hline Babyhaler & $350 \mathrm{~mL}$ & $\begin{array}{l}\text { Polycarbonate, } \\
\text { non-electrostatic }\end{array}$ & $\begin{array}{l}\text { Internal circular unidirectional silicon valve hinged centrally, aerosol passe } \\
\text { at the valve periphery, additional top outside valve }\end{array}$ \\
\hline Compact Space Chamber Plus & $160 \mathrm{~mL}$ & ABS, antistatic & Internal silicon valve with central cross shaped opening \\
\hline DispoZABLE spacer & $\mathrm{N} / \mathrm{A}$ & Cardboard & No valve. No Mask. \\
\hline InspiraChamber & $\mathrm{N} / \mathrm{A}$ & ABS, antistatic & $\begin{array}{l}\text { Internal cone shaped unidirectional silicon valve, aerosol passes through the } \\
\text { valve centrally }\end{array}$ \\
\hline LiteAire Disposable & N/A & Cardboard & Dual plastic sheet valves. Disposable spacer. No mask. \\
\hline $\begin{array}{l}\text { Livingstone Disposable } \\
\text { Cardboard Asthma Spacer }\end{array}$ & $\mathrm{N} / \mathrm{A}$ & Cardboard & Dual plastic sheet valves. Disposable spacer. No mask. \\
\hline Optichamber diamond & $140 \mathrm{~mL}$ & ABS, antistatic & $\begin{array}{l}\text { Internal cone shaped unidirectional silicon valve, aerosol passes through the } \\
\text { valve centrally, additional top outside expiratory valve }\end{array}$ \\
\hline ProChamber & $145 \mathrm{~mL}$ & ABS, antistatic & $\begin{array}{l}\text { Internal cone shaped unidirectional silicon valve, aerosol passes through the } \\
\text { valve centrally }\end{array}$ \\
\hline Rossmax Aero Spacer & $175 \mathrm{~mL}$ & ABS, antistatic & $\begin{array}{l}\text { Internal circular unidirectional silicon valve, aerosol passes through the } \\
\text { valve centrally }\end{array}$ \\
\hline Tipshaler & N/A & N/A & $\begin{array}{l}\text { Internal cone shaped unidirectional silicon valve, aerosol passes through the } \\
\text { valve centrally }\end{array}$ \\
\hline Volumatic & $750 \mathrm{~mL}$ & $\begin{array}{l}\text { Polycarbonate, } \\
\text { non-electrostatic }\end{array}$ & $\begin{array}{l}\text { Internal rigid circular plastic valve, aerosol passes at the valve periphery. } \\
\text { No mask. }\end{array}$ \\
\hline Vortex & $194 \mathrm{~mL}$ & $\begin{array}{l}\text { Aluminum, reduced static } \\
\text { charge }\end{array}$ & $\begin{array}{l}\text { Internal cone shaped unidirectional silicon valve, aerosol passes through the } \\
\text { valve centrally }\end{array}$ \\
\hline
\end{tabular}

*Manufacturers use several different terms: antistatic, non-electrostatic or reduced static charge. All non-conductive materials (such as ABS, polycarbonate, and cardboard) are prone to accumulate electrostatic charge.

ABS, acrylonitrile butadiene styrene

N/A, not available

\section{Effect of the respiratory pattern on drug delivery through VHCs}

Drug delivery through VHCs is shown to be dependent on the breathing pattern and respiratory characteristics of the patients, both in vivo and in experimental models [17, 29-33, 35]. Inspiratory flow rate (PIFR) is linearly correlated with Vt $[29,34]$ and asthmatic patients have a wider range of PIFR compared with healthy subjects [34].

Increasing $\mathrm{Vt}$ is associated with increasing drug delivery. Chavez and colleagues [36] found in an in vitro study using AeroChamber Max® that when gradually increasing the $\mathrm{Vt}$ from 36 to $290 \mathrm{ml}$, the filter dose of albuterol increased in a logarithmic fashion with both RRs of 12 and $24 \mathrm{~L} / \mathrm{min}$.

During bronchoconstriction, Vt decreases and respiratory rate (RR) increases. The drug delivery capacity seems to be sensitive to shallow and rapid respiratory
Valve characteristics and additional features

Internal circular unidirectional silicon valve, aerosol passes through the ternal circular unidirectional silicon valve, aerosol passes at the valve

ternal silicon valve with central cross shaped opening

No valve. No Mask.

ternal cone shaped unidirectional silicon valve, aerosol passes through the

Internal cone shaped unidirectional silicon valve, aerosol passes through the

\section{valve centrally}

ternal circular unidirectional silicon valve, aerosol passes through the

valve centrally

ternal rigid circular plastic valve, aerosol passes at the valve periphery.

ternal cone shaped unidirectional silicon valve, aerosol passes through the valve centrally 
Table 2 Overview of the current treatment guidelines of optimal administration of bronchodilators with valved hold chambers (VHCs) in preschool children and further recommendations by the current review. $p M D I$ pressurized metered dose inhalers

\begin{tabular}{|c|c|c|c|c|c|c|}
\hline Guideline & $\begin{array}{l}\text { pMDI+VHC } \\
\text { or nebulizer }\end{array}$ & $\begin{array}{l}\text { Recommendation } \\
\text { concerning the choice } \\
\text { of } \mathrm{VHC}\end{array}$ & $\begin{array}{l}\text { Recommendation } \\
\text { concerning the face } \\
\text { mask usage and seal }\end{array}$ & Notes on cooperation & $\begin{array}{l}\text { Number of } \\
\text { puffs to be } \\
\text { used at a time }\end{array}$ & $\begin{array}{l}\text { Recommendation } \\
\text { concerning VHC handling }\end{array}$ \\
\hline GINA [9] & pMDI+VHC & $\begin{array}{l}\text { Indicates that young } \\
\text { children can use } \\
\text { spacers of all sizes, } \\
\text { but a lower volume } \\
\text { spacer }(<350 \mathrm{~mL}) \\
\text { is advantageous in } \\
\text { very young } \\
\text { children. }\end{array}$ & $\begin{array}{l}\text { Instructs that a tightly } \\
\text { fitting face mask } \\
\text { should be used for } \\
\text { children under } 4 \\
\text { years. Face mask } \\
\text { should be switched } \\
\text { to mouthpiece as } \\
\text { soon as children } \\
\text { are able to } \\
\text { demonstrate good } \\
\text { technique. }\end{array}$ & No specific notes. & One & $\begin{array}{l}\text { States that to reduce static } \\
\text { charge, plastic VHC } \\
\text { should be pre-washed } \\
\text { with detergent and } \\
\text { air-dried to be ready for } \\
\text { immediate use. }\end{array}$ \\
\hline Australia [10] & $\mathrm{pMDI}+\mathrm{VHC}$ & $\begin{array}{l}\text { Mentions that there } \\
\text { are different types } \\
\text { of VHC but does } \\
\text { not recommend } \\
\text { any one specific } \\
\text { VHC for acute } \\
\text { treatment. }\end{array}$ & $\begin{array}{l}\text { Instructs that a } \\
\text { well-fitted mask } \\
\text { should be used for } \\
\text { small children who } \\
\text { cannot form a tight } \\
\text { seal with their lips } \\
\text { around the spacer } \\
\text { mouthpiece. }\end{array}$ & $\begin{array}{l}\text { Remarks that babies } \\
\text { are unlikely to } \\
\text { inhale enough } \\
\text { medicine while } \\
\text { crying and there } \\
\text { should be extra } \\
\text { effort to calm the } \\
\text { children down in } \\
\text { order to ensure } \\
\text { adequate } \\
\text { therapeutic effect. }\end{array}$ & One & $\begin{array}{l}\text { States that to reduce } \\
\text { electrostatic charge } \\
\text { standard plastic VHC } \\
\text { should be pre-washed } \\
\text { with detergent. } \\
\text { Treatment to reduce } \\
\text { electrostatic charge is not } \\
\text { necessary for cardboard } \\
\text { and } \\
\text { polyurethane/antistatic } \\
\text { polymer spacers. }\end{array}$ \\
\hline USA [13] & pMDI+VHC & $\begin{array}{l}\text { Indicates that due to } \\
\text { the significant } \\
\text { variation found } \\
\text { between the } \\
\text { performance of } \\
\text { specific VHCs and } \\
\text { pMDIs, it may be } \\
\text { preferable to use } \\
\text { the same } \\
\text { combination of } \\
\text { pMDI+VHC } \\
\text { reported in the } \\
\text { individual drug } \\
\text { study to achieve } \\
\text { comparable results. }\end{array}$ & $\begin{array}{l}\text { Instructs that a tightly } \\
\text { fitting face mask } \\
\text { should be used for } \\
\text { children under } 4 \\
\text { years and for those } \\
\text { who are unable to } \\
\text { use mouthpiece. }\end{array}$ & No specific notes. & One & $\begin{array}{l}\text { Instructs to use antistatic } \\
\text { VHCs or to rinse static } \\
\text { plastic VHCs with dilute } \\
\text { household detergents to } \\
\text { enhance delivery to } \\
\text { lungs and efficacy. }\end{array}$ \\
\hline UK [11] & pMDI+VHC & $\begin{array}{l}\text { Indicates that each } \\
\text { VHC should be } \\
\text { compatible with } \\
\text { the pMDI being } \\
\text { used and that the } \\
\text { change in VHC } \\
\text { may alter effective } \\
\text { dose delivered. }\end{array}$ & $\begin{array}{l}\text { Instructs that a face } \\
\text { mask should be } \\
\text { used for those who } \\
\text { are unable to use } \\
\text { mouthpiece. Does } \\
\text { not mention about } \\
\text { the face mask fit. }\end{array}$ & No specific notes. & One & $\begin{array}{l}\text { Instructs that VHCs should } \\
\text { be cleaned monthly } \\
\text { rather than weekly as per } \\
\text { manufacturer's } \\
\text { recommendations or } \\
\text { performance is adversely } \\
\text { affected. }\end{array}$ \\
\hline Canada [12] & pMDI+VHC & $\begin{array}{l}\text { No specific } \\
\text { recommendations. }\end{array}$ & $\begin{array}{l}\text { Indicates that for } \\
\text { children 1-3 years } \\
\text { of age, a VHC with } \\
\text { a correctly sized } \\
\text { facemask is pre- } \\
\text { ferred. Does not } \\
\text { mention about the } \\
\text { face mask fit. }\end{array}$ & No specific notes. & $\begin{array}{l}\text { Not } \\
\text { mentioned. }\end{array}$ & $\begin{array}{l}\text { No specific } \\
\text { recommendations. }\end{array}$ \\
\hline Finland $[8,14]$ & pMDI+VHC & $\begin{array}{l}\text { No specific } \\
\text { recommendations. }\end{array}$ & $\begin{array}{l}\text { Instructs that a face } \\
\text { mask should be } \\
\text { used for children } \\
\text { under } 3 \text { years. } \\
\text { Does not mention }\end{array}$ & No specific notes. & $\begin{array}{l}\text { Not } \\
\text { mentioned. }\end{array}$ & $\begin{array}{l}\text { No specific } \\
\text { recommendations. }\end{array}$ \\
\hline
\end{tabular}


Table 2 (continued)

\begin{tabular}{|c|c|c|c|c|c|c|}
\hline Guideline & $\begin{array}{l}\text { pMDI+VHC } \\
\text { or nebulizer }\end{array}$ & $\begin{array}{l}\text { Recommendation } \\
\text { concerning the choice } \\
\text { of } \mathrm{VHC}\end{array}$ & $\begin{array}{l}\text { Recommendation } \\
\text { concerning the face } \\
\text { mask usage and seal }\end{array}$ & Notes on cooperation & $\begin{array}{l}\text { Number of } \\
\text { puffs to be } \\
\text { used at a time }\end{array}$ & $\begin{array}{l}\text { Recommendation } \\
\text { concerning VHC handling }\end{array}$ \\
\hline $\begin{array}{l}\text { Current evidence } \\
\text { and further } \\
\text { recommenda- } \\
\text { tions by the } \\
\text { current review }\end{array}$ & $\begin{array}{l}\text { Evidence } \\
\text { supports } \\
\text { using } \\
\text { pMDI+ } \\
\text { VHC } \\
\text { instead of } \\
\text { a } \\
\text { nebulizer. } \\
\text { Current } \\
\text { guidelines } \\
\text { are in line } \\
\text { with the } \\
\text { evidence. }\end{array}$ & $\begin{array}{l}\text { There are } \\
\text { considerable } \\
\text { differences in drug } \\
\text { delivery between } \\
\text { VHCs, but their } \\
\text { clinical } \\
\text { implications are } \\
\text { not known. } \\
\text { Guidelines should } \\
\text { note that the dose } \\
\text { output of different } \\
\text { VHC models vary } \\
\text { significantly and } \\
\text { VHCs may not be } \\
\text { interchangeable. } \\
\text { Future studies are } \\
\text { needed to assess } \\
\text { the clinical effect } \\
\text { of these } \\
\text { differences. }\end{array}$ & $\begin{array}{l}\text { about the face } \\
\text { mask fit. } \\
\text { Face mask should be } \\
\text { used in children } \\
\text { who are unable to } \\
\text { hold the VHC's } \\
\text { mouthpiece } \\
\text { between the lips. } \\
\text { Tight fit and good } \\
\text { seal between the } \\
\text { mask and face is } \\
\text { essential for drug } \\
\text { delivery. } \\
\text { Guidelines are in line } \\
\text { with the evidence } \\
\text { in recommending } \\
\text { the use of face } \\
\text { masks. Guidelines } \\
\text { should also } \\
\text { emphasize that to } \\
\text { ensure optimal } \\
\text { drug delivery good } \\
\text { face mask fit } \\
\text { should be routinely } \\
\text { check before and } \\
\text { during drug } \\
\text { administration. } \\
\text { Face mask should } \\
\text { be omitted as soon } \\
\text { as the child is able } \\
\text { to hold the } \\
\text { mouthpiece tightly } \\
\text { between the lips. }\end{array}$ & $\begin{array}{l}\text { Crying and poor } \\
\text { co-operation of the } \\
\text { child may signifi- } \\
\text { cantly decrease } \\
\text { pulmonary drug } \\
\text { delivery. } \\
\text { Guidelines should } \\
\text { indicate that crying } \\
\text { and poor } \\
\text { co-operation dur- } \\
\text { ing inhalation may } \\
\text { significantly re- } \\
\text { duce pulmonary } \\
\text { drug delivery. } \\
\text { Calming the child } \\
\text { is important for } \\
\text { optimal drug deliv- } \\
\text { ery. }\end{array}$ & $\begin{array}{l}\text { Better drug } \\
\text { delivery } \\
\text { can be } \\
\text { achieved } \\
\text { by inhaling } \\
\text { each dose } \\
\text { separately. } \\
\text { Most of the } \\
\text { guidelines } \\
\text { are in line } \\
\text { with the } \\
\text { evidence, } \\
\text { but this } \\
\text { should be } \\
\text { noted in } \\
\text { every } \\
\text { guideline. }\end{array}$ & $\begin{array}{l}\text { Different chamber } \\
\text { materials have variable } \\
\text { electrostatic properties } \\
\text { and VHC handling may } \\
\text { significantly affect drug } \\
\text { delivery. } \\
\text { Future } \\
\text { sponsor-independent } \\
\text { studies are needed to } \\
\text { evaluate the clinical im- } \\
\text { pact of the electrostatic } \\
\text { effect and antistatic } \\
\text { treatment of VHCs. }\end{array}$ \\
\hline
\end{tabular}

by age and during bronchoconstriction is not specifically addressed the guidelines.

\section{Effect of face mask, face mask seal, and patient co- operation on drug delivery with VHCs}

Face masks are used to facilitate drug delivery in young children who are incapable of holding a mouthpiece between the lips and teeth [9]. However, drug delivery is lower when face mask is used $[17,36]$. Children older than 3-4 years of age are generally able to use VHC without masks [9], and most guidelines recommend that face mask should be omitted as soon as children are able to demonstrate good technique [8-11, 13].

A good seal with a minimal leak around the nose, cheeks, and mouth will ensure inspiration through the VHC and prevents ingress of ambient air between the mask and face [37, 38]. Several in vitro studies have shown that leakage due to the lack of a tight mask-to-face seal has a large impact on aerosol delivery $[17,20,37,39-41]$. Even a minor air leak between the face and the mask can drastically reduce aerosol delivery and depending on the location and size of the mask leak, and drug delivery can drop almost to an undetectable level [41]. According to Esposito-Festen et al. [41], the lung dose seems to decrease more rapidly when the mask leak is located close to the nose relative to a leak near the chin. The overall design, volume, and degree of adaptability of the face mask are important factors that influence the fit and mask-toface seal as well as the physical dead space of the mask [32]. When pressed against the face, pressure causes compression of the mask, tightening the contact and reducing the actual dead space of the mask $[42,43]$. However, with increasing pressure against the face, children are more likely to cry which again decreases the inhaled dose [44-46].

When aerosol is inhaled during crying, lung deposition decreases significantly [46, 47]. In a study by Erzinger at al. [45], lung deposition of radiolabeled drug relative to the total nominal dose was $0.2-0.3 \%$ in children who inhaled with a non-tightly fitted face mask. The deposition was $0.6-1.4 \%$ in 
screaming children with a tightly fitted face mask and 4.8$8.2 \%$ in patients inhaling quietly. Approximately $2-5$ breaths per actuation seem to be enough to empty the VHC $[23,25$, 48]. However, the optimal number of breaths required to empty the VHC depends on the child's Vt, the volume of the VHC and valve dead space.

Guidelines are in line with the evidence in recommending the use of face masks for younger children, but they do not fully endorse good face mask fit or the importance of calming the child to improve co-operation and drug delivery (Table 2).

\section{Impact of taking each puff separately vs. multiple puffs simultaneously}

Clark and Lipworth [49] measured higher plasma salbutamol levels per actuation and greater systemic responses after inhaling each puff separately from the Volumatic VHC $(750 \mathrm{~mL})$ compared with either inhaling multiple puffs simultaneously or taking single puffs with delayed inhalation. Also using the Volumatic, Barry and O'Callaghan [50] found that compared with single actuation, double actuation for one inhalation decreased drug recovery by $22 \%$ per $100 \mu \mathrm{g}$ actuation and quintuple actuation decreased it by $62 \%$ per $100 \mu \mathrm{g}$ actuation. In the study by Wildhaber et al. [51], the total amount of salbutamol delivery from Babyhaler $(350 \mathrm{~mL})$ was reduced by $17 \%$ per actuation for two puffs at a time and by $22 \%$ per actuation for five puffs at a time. In the same study the differences in drug delivery for multiple actuations from the antistatically treated Babyhaler and the antistatic Nebuchamber were less pronounced but still statistically significant. The effect of multiple actuations may vary depending on the VHC brand. In the study by Csonka and Lehtimäki [52], four out of the six VHCs examined showed significantly poorer performance per actuation with two puffs as opposed to one puff. The reason for the variable effect of puffs is not well known, but multiple actuations may influence the overall aerodynamic environment and drug flow within the chamber.

There is clear evidence that better drug delivery can be achieved by inhaling each dose separately. Most of the guidelines are in line with the evidence, but this should be noted in every guideline (Table 2).

\section{Electrostatic charge and detergents have variable effects on drug VHC delivery}

Static electricity is an imbalance of electric charges within or on the surface of a material. Materials that have a low electrical resistance are called conductive, since they allow electrons to flow easily across the surface or through the material. Conductive materials-for example aluminum and steel-are less static compared with non-conductive materials. Non-conductive materials, such as plastic or cardboard, are always prone to build up static charge. The polarity and strength of the charges differ according to the compound used, surface roughness, ambient temperature, rinsing, and other properties. In addition, anti-static coating can reduce the triboelectric effect but cannot completely diminish it. The most challenging characteristic of the triboelectric effect is unpredictability.

Many in vitro and in vivo studies have demonstrated that drug delivery from non-conductive (e.g., polycarbonate or polyester) VHCs that are prone to static electricity is typically improved by pre-washing in detergent solution and air-drying, or via other means of antistatic coating [31, 53-55]. Performance differences exist also between those plastic VHCs that are marketed by the manufacturer as antistatic (e.g. acrylonitrile butadiene styrene (ABS)) and even between conductive (e.g. metal) VHCs [19, 31, $52,55-59]$. Reducing the charge by coating the chamber surface with ionic detergent has been shown to result in an increase of $50-70 \%$ in fine particle $(<6.8 \mu \mathrm{m})$ delivery from a large polycarbonate VHC (Volumatic) [54] as well as from five small volume plastic (polycarbonate and ABS) and metal VHCs in vitro [51]. In another study, washing volumatic with plain water was as effective as an antistatic lining in reducing the effects of static charge on salbutamol delivery in vivo [49]. Similarly, the study by Dompeling et al. [56] found that despite their difference in static properties, plastic VHCs (Aerochamber and Volumatic) and the metal Nebuchamber were equally effective regarding the clinical efficacy of salbutamol in children with asthma. On the other hand, Csonka and Lehtimäki [52] detected a significant reduction in the performance of Babyhaler (polycarbonate) and A2A (ABS) after detergent washing. Hatley et al. [60] found that the performance of the Optichamber Diamond (ABS), when taken out of its original packaging and used for the first time, was not influenced by washing in soapy water.

The effect of static charge of VHCs has translated to variable effects on lung deposition and lung function [19, 31, 55-58]. Piérart et al. [31] found that the mean lung deposition of radiolabeled salbutamol in healthy subjects was $46 \%$ through a detergent-coated volumatic compared with $12 \%$ through an untreated static VHC. A study by Anhøj et al. [55] reported that the antistatically treated Babyhaler delivered a significantly higher lung dose than either untreated Babyhaler or AeroChamber (ABS). In the study by Dompeling et al. [56] electrostatic charge on plastic VHCs had no significant influence on the clinical efficacy of salbutamol in children with asthma. The Nebuchamber (metal), Aerochamber (ABS), and Volumatic (polycarbonate) were equally effective [56]. The in vivo study by Janssens et al. [57] involving 1-4 years old children detected significantly $(p<0.001)$ higher mean filter dose $(41.7 \pm 10.1 \%)$ using metal Nebuchamber compared with polycarbonate 
Babyhaler $26.0 \pm 4.0 \%$. Another study found no differences in specific airway resistance or FEV1 following a methacholine challenge in children administered salbutamol via an untreated Babyhaler, a detergent washed Babyhaler or a metal Nebuchamber [58].

Evidence suggests that different chamber materials have variable electrostatic properties and that VHC handling may significantly affect drug delivery. Some guidelines address the issue of VHC static charge (Table 2), but there are no specific recommendations about the ideal chamber composition and as to how and with which detergent should the VHCs be pre-treated. Future sponsorindependent studies are needed to evaluate the clinical impact of the electrostatic effect and antistatic treatment of VHCs.

Table 3 Recommendations on how to use a pMDI and VHC in preschool children

These are general recommendations and the nuances may vary depending on the child's age and device model.

General notes:

- Always check that the VHC is intact and the valves are correctly positioned and working properly.

- Face mask should be used in children younger than three years of age and for those who are unable to hold the VHC's mouthpiece between the lips.

- Tight fit and good seal between the mask and face is essential for drug delivery. Choose the correct size mask.

- Crying and poor co-operation of the child during inhalation may significantly decrease pulmonary drug delivery. Invest in calming the child but administer the medication as soon as possible.

- Always actuate one puff at a time into the VHC.

Drug delivery step by step

1. Explain to the child, what you are about to do and why. Calm the child if he/she is agitated.

2. Position the child sitting up straight with face slightly upwards. Support the child's body and head gently but firmly. With small children you may need extra helping hands.

3. Remove the pMDI cap.

4. Shake the pMDI vigorously five times.

5. Hold the pMDI upright and place it firmly into the VHC.

6. Keep the pMDI+VHC unit in a horizontal position and place the face mask or mouthpiece meticulously:

6.1. In case a face mask is used, make sure the face mask is of correct size. It should cover the mouth and nose comfortably. Look around the mask's perimeter and make sure that the mask is touching the face all around and there is no leak between the mask and face. Adjust the fit if necessary.

6.2. If the mask is not needed, place the mouthpiece between the teeth and make sure the lips are tightly sealed around the mouthpiece without gaps.

7. If the child is crying or resisting, take some time to calm the child.

8 . When the VHC is properly positioned and the child is inhaling calmly, actuate the pMDI once.

9. Let the child breath for at least five breathing cycles before you remove the VHC.

10. If additional doses are needed, repeat the whole process from step 4. onwards.

\section{Conclusions}

We found strong evidence to support several recommendations in current guidelines. Face mask should be omitted when the child can hold the mouthpiece of the VHC tightly between the lips and teeth. In addition, each puff of salbutamol should be given separately without delay, i.e., one puff per $2-5$ inhalations.

Based on the systematic review, we suggest adding a specific note to the current guidelines about the impact of cooperation during drug administration. Calming the child and securing a tight face-to-mask seal is critical for successful drug delivery. Guidelines could benefit from more elaborate instructions on drug administration with valved holding chambers in preschool children (Table 3.)

Although some guidelines address the issue of VHC static charge, there is insufficient data to make recommendations on ideal chamber material and antistatic treatment. Published data suggest that different VHCs and their masks cannot be assumed to be equally effective in drug delivery for bronchodilator administration, but there is not enough evidence to make specific recommendations on the most reliable and effective VHC delivery system. More research is needed about the optimal choice of pMDI+VHC combination for children at different age groups and with different respiratory patterns.

Abbreviations ABS, Acrylonitrile butadiene styrene; ER, Emergency room; PIFR, Peak inspiratory flow rate; pMDI, Pressurized metered dose inhalers; RR, Respiratory rate; VHC, Valved holding chambers; Vt, Tidal volume

Authors' contributions All authors have made substantial contributions to the conception and design of the work, analysis and or interpretation of data; drafted and revised the work critically for intellectual content; approved the version to be published; and agree to be accountable for all aspects of the work in ensuring that questions related to the accuracy or integrity of any part of the work are appropriately investigated and resolved.

Funding This study was supported by the Tampere Tuberculosis Foundation and the Research Foundation of the Pulmonary Disease.

Data availability If requested.

Code availability N/A

\section{Declarations}

Ethics approval N/A

Consent to participate N/A

Consent for publication participate N/A 
Conflict of interests None of the authors have any conflict of interest regarding this paper.

Open Access This article is licensed under a Creative Commons Attribution 4.0 International License, which permits use, sharing, adaptation, distribution and reproduction in any medium or format, as long as you give appropriate credit to the original author(s) and the source, provide a link to the Creative Commons licence, and indicate if changes were made. The images or other third party material in this article are included in the article's Creative Commons licence, unless indicated otherwise in a credit line to the material. If material is not included in the article's Creative Commons licence and your intended use is not permitted by statutory regulation or exceeds the permitted use, you will need to obtain permission directly from the copyright holder. To view a copy of this licence, visit http://creativecommons.org/licenses/by/4.0/.

\section{References}

1. Csonka P, Mertsola J, Klaukka T, Kaila M, Ståhlberg MR, Ashorn P (2000) Corticosteroid therapy and need for hospital care in wheezing preschool children. Eur J Clin Pharmacol 56:591-596. https://oi.org/10.1007/s002280000199

2. Mecklin M, Paassilta M, Kainulainen H, Korppi M (2011) Emergency treatment of obstructive bronchitis: change from nebulizers to metered dose inhalers with spacers. Acta Paediatr 100: 1226-1229. https://doi.org/10.1111/j.1651-2227.2011.02267.x

3. Cates CJ, Welsh EJ, Rowe BH (2013) Holding chambers (spacers) versus nebulisers for beta-agonist treatment of acute asthma. Cochrane Database Syst Rev 13:CD000052. https://doi.org/10. 1002/14651858.CD000052.pub3

4. Castro-Rodriguez JA, Rodrigo GJ (2004) $\beta$-agonists through metered-dose inhaler with valved holding chamber versus nebulizer for acute exacerbation of wheezing or asthma in children under 5 years of age: A systematic review with meta-analysis. J Pediatr 145: 172-177

5. Delgado A, Chou KJ, Johnson Silver E et al (2003) Nebulizers vs metered-dose inhalers with spacers for bronchodilator therapy to treat wheezing in children aged 2 to 24 months in a pediatric emergency department. Arch Pediatr Adolesc Med 157:76-80. https:// doi.org/10.1001/archpedi.157.1.76

6. Deerojanawong J, Manuyakorn W, Prapphal N, Harnruthakorn C, Sritippayawan S, Samransamruajkit R (2005) Randomized controlled trial of salbutamol aerosol therapy via metered dose inhaler-spacer vs. jet nebulizer in young children with wheezing. Pediatr Pulmonol 39:466-472. https://doi.org/10.1002/ppul.20204

7. Parkin PC, Saunders NR, Diamond SA, Winders PM, Macarthur C (1995) Randomised trial spacer v nebuliser for acute asthma. Arch Dis Child 72:239-240. https://doi.org/10.1136/adc.72.3.239

8. (2012) Asthma - Finnish Current Care Guidelines. In: Helsinki Finnish Med. Soc. Duodecim. https://www.kaypahoito.fi/ hoi06030. Accessed 20 Sep 2020

9. (2020) Global Strategy for Asthma Management and Prevention (2020 update). https://ginasthma.org/gina-reports. Accessed 6 Sep 2020

10. National Asthma Council Australia Australian Asthma Handbook, Version 2.1. In: 2020. https://www.asthmahandbook.org.au/. Accessed 20 Oct 2020

11. (2019) British guideline on the management of asthma - SIGN 158. https://www.brit-thoracic.org.uk/quality-improvement/guidelines/ asthma/. Accessed 20 Oct 2020

12. (2012) Managing the paediatric patient with an acute asthma exacerbation - Canadian Paediatric Society (Reaffirmed: Jan 30, 2017). https:/www.cps.ca/en/documents/position/management-acuteasthma-exacerbation. Accessed 15 Oct 2020

13. (2007) Guidelines for the Diagnosis and Management of Asthma Full Report. https://www.nhlbi.nih.gov/files/docs/guidelines/ asthgdln.pdf. Accessed 20 Oct 2020

14. Working group set up by the Finnish Medical Society Duodecim, The Finnish Paediatric Society and TFS of GP (2015) Treatment of lower respiratory tract infections in children - Finnish Current Care Guidelines. https://www.kaypahoito.fi/hoi50098. Accessed 18 Sep 2019

15. Fink JB, Ehrmann S, Li J et al (2020) Reducing Aerosol-Related Risk of Transmission in the Era of COVID-19: An Interim Guidance Endorsed by the International Society of Aerosols in Medicine. J Aerosol Med Pulm Drug Deliv 33:jamp.2020.1615. https://doi.org/10.1089/jamp.2020.1615

16. (2020) Global Initiative for Asthma. COVID-19: GINA answers to frequently asked questions on asthma management. https:// ginasthma.org/covid-19-gina-answers-to-frequently-askedquestions-on-asthma-management/. Accessed 10 Dec 2020

17. Csonka P, Lehtimäki L (2019) In vitro drug delivery performance of five valved holding chambers with and without facemasks. Pediatr Pulmonol 54:1457-1465. https://doi.org/10.1002/ppul. 24425

18. Barry PW, O'Callaghan C (1997) In vitro comparison of the amount of salbutamol available for inhalation from different formulations used with different spacer devices. Eur Respir J 10:13451348. https://doi.org/10.1183/09031936.97.10061345

19. Janssens HM, Heijnen EMEW, De Jong VM et al (2000) Aerosol delivery from spacers in wheezy infants: A daily life study. Eur Respir J 16:850-856. https://doi.org/10.1088/0953-8984/1/25/010

20. Häselbarth J, Svedmyr J (2020) Paediatric in vitro models showed significant variations in fluticasone proprionate output from valved holding chambers. Acta Paediatr 109:565-572. https://doi.org/10. 1111/apa.14965

21. Finlay WH, Zuberbuhler P (1998) In vitro comparison of beclomethasone and salbutamol metered-dose inhaler aerosols inhaled during pediatric tidal breathing from four valved holding chambers. Chest 114:1676-1680. https://doi.org/10.1378/chest. 114.6.1676

22. Csonka P, Lehtimäki L (2019) Valved holding chamber drug delivery is dependent on breathing pattern and device design. ERJ Open Res 4:5(1). https://doi.org/10.1183/23120541.00158-2018

23. Bateman ED, Hurd SS, Barnes PJ, Bousquet J, Drazen JM, FitzGerald M, Gibson P, Ohta K, O'Byrne P, Pedersen SE, Pizzichini E, Sullivan SD, Wenzel SE, Zar HJ (2008) Global strategy for asthma management and prevention: GINA executive summary. Eur Respir J 31:143-178. https://doi.org/10.1183/09031936. 00138707

24. Mitchell JP, Nagel MWMM (1997) In vitro performance testing of three small volume-holding chambers under conditions that correspond with use by infants and small children. J Aerosol Med 10: 341-349. https://doi.org/10.1089/jam.1997.10.341

25. Berg E, Madsen J, Bisgaard H (1998) In vitro performance of three combinations of spacers and pressurized metered dose inhalers for treatment in children. Eur Respir J 12:472-476. https://doi.org/10. 1183/09031936.98.12020472

26. Dubus J, Anhøj J (2004) Inhaled steroid delivery from smallvolume holding. J Aerosol Med 17:225-230

27. Turpeinen M, Nikander K, Malmberg LP et al (1999) Metered dose inhaler add-on devices: is the inhaled mass of drug dependent on the size of the infant? J Aerosol Med 12:171-176. https://doi.org/ 10.1089/jam.1999.12.171

28. Csonka P, Lehtimaki L (2018) Valved holding chambers vary considerably in drug delivery efficacy:OA340. https://doi.org/10.1183/ 13993003.congress-2018.oa340 
29. Schultz A, Le Souëf TJ, Looi K et al (2010) Validation of methodology for recording breathing and simulating drug delivery through spacers and valved holding chambers. J Aerosol Med Pulm Drug Deliv 23:311-322. https://doi.org/10.1089/jamp.2008.0733

30. Vincken W, Levy ML, Scullion J, Usmani OS, Dekhuijzen PNR, Corrigan CJ (2018) Spacer devices for inhaled therapy: why use them, and how? ERJ Open Res 4:1-10. https://doi.org/10.1183/ 23120541.00065-2018

31. Piérart F, Wildhaber JHH, Vrancken I et al (1999) Washing plastic spacers in household detergent reduces electrostatic charge and greatly improves delivery. Eur Respir J 13:673-678. https://doi. org/10.1183/09031936.99.13367399

32. Janssens HM, Krijgsman A, Verbraak TFM, Hop WCJ, de Jongste JC, Tiddens HAWM (2004) Determining factors of aerosol deposition for four pMDI-spacer combinations in an infant upper airway model. J Aerosol Med 17:51-61. https://doi.org/10.1089/ 089426804322994460

33. Everard ML, Clark AR, Milner AD (1992) Drug delivery from holding chambers with attached facemask. Arch Dis Child 67: 580-585. https://doi.org/10.1136/adc.67.5.580

34. Nikander K, Denyer J (2000) Breathing patterns. Eur Respir Rev 10:576-579

35. Barry PW, O'Callaghan C (1999) The output of budesonide from spacer devices assessed under simulated breathing conditions. J Allergy Clin Immunol 104:1205-1210. https://doi.org/10.1016/ S0091-6749(99)70014-X

36. Chavez A, McCracken A, Berlinski A (2010) Effect of face mask dead volume, respiratory rate, and tidal volume on inhaled albuterol delivery. Pediatr Pulmonol 45:224-229. https://doi.org/10.1002/ ppul.21156

37. Amirav I, Newhouse M (2001) Aerosol therapy with valved holding chambers in young children: importance of the facemask seal. Pediatrics 108:389-394. https://doi.org/10.1542/peds.108.2.389

38. Janssens HM, Tiddens HAWM (2007) Facemasks and Aerosol Delivery by Metered Dose Inhaler-Valved Holding Chamber in Young Children: A Tight Seal Makes the Difference. J Aerosol Med 20:S59-S65. https://doi.org/10.1089/jam.2007.0578

39. Hayden JT, Smith N, Woolf DA, Barry PW, O'Callaghan C (2004) A randomised crossover trial of facemask efficacy. Arch Dis Child 89:72-73

40. Smaldone GC, Berg E, Nikander K (2005) Variation in pediatric aerosol delivery: importance of facemask. J Aerosol Med 18:354 363. https://doi.org/10.1089/jam.2005.18.354

41. Esposito-Festen JEE, Ates B, van Vliet FJMJM et al (2004) Effect of a facemask leak on aerosol delivery from a pMDI-spacer system. J Aerosol Med 17:1-6. https://doi.org/10.1089/ 089426804322994406

42. Shah SA, Berlinski A, Rubin BK (2006) Force-dependent static dead space of face masks used with holding chambers. Respir Care 51:140-144

43. Amirav I, Luder AS, Halamish A, Marzuk C, Daitzchman M, Newhouse MT (2015) Computerized dead-space volume measurement of face masks applied to simulated faces. Respir Care 60: 1247-1251. https://doi.org/10.4187/respcare.03813

44. Nikander K, Berg E, Smaldone GC (2007) Jet nebulizers versus pressurized metered dose inhalers with valved holding chambers: effects of the facemask on aerosol delivery. J Aerosol Med 20:S46S58. https://doi.org/10.1089/jam.2007.0588

45. Erzinger S, Schueepp KG, Brooks-Wildhaber J, Devadason SG, Wildhaber JH (2007) Facemasks and aerosol delivery in vivo. J Aerosol Med 20:S78-S84. https://doi.org/10.1089/jam.2007.0572

46. Iles R, Lister P, Edmunds AT (1999) Crying significantly reduces absorption of aerosolised drug in infants. Arch Dis Child 81:163165. https://doi.org/10.1136/adc.81.2.163
47. Murakami G, Igarashi T, Adachi Y, Matsuno M, Adachi Y, Sawai M, Yoshizumi A, Okada T (1990) Measurement of bronchial hyperreactivity in infants and preschool children using a new method. Ann Allergy 64:383-387

48. Schultz A, Le Souef TJ, Venter A et al (2010) Aerosol inhalation from spacers and valved holding chambers requires few tidal breaths for children. Pediatrics 126:e1493-e1498. https://doi.org/ 10.1542/peds.2010-1377

49. Clark DJ, Lipworth BJ (1996) Effect of multiple actuations, delayed inhalation and antistatic treatment on the lung bioavailability of salbutamol via a spacer device. Thorax 51:981-984. https://doi. org/10.1136/thx.51.10.981

50. Barry PW, O'Callaghan C (1994) Multiple actuations of salbutamol MDI into a spacer device reduce the amount of drug recovered in the respirable range. Eur Respir J 7:1707-1709. https://doi.org/10. 1183/09031936.94.07091707

51. Wildhaber JH, Devadason SG, Eber E, Hayden MJ, Everard ML, Summers QA, LeSouef PN (1996) Effect of electrostatic charge, flow, delay and multiple actuations on the in vitro delivery of salbutamol from different small volume spacers for infants. Thorax 51:985-988. https://doi.org/10.1136/thx.51.10.985

52. Csonka P, Lehtimäki L (2019) Antistatic treatment and salbutamol dosing have variable effect on drug delivery of valved holding chambers. Pulm Pharmacol Ther 59:101857. https://doi.org/10. 1016/j.pupt.2019.101857

53. Barry PW, O'Callaghan C, Callaghan CO et al (1995) The effect of delay, multiple actuations and spacer static charge on the in vitro delivery of budesonide from the Nebuhaler. Br J Clin Pharmacol 40:76-78. https://doi.org/10.1111/j.1365-2125.1995.tb04538.x

54. Wildhaber JH, Devadason SG, Hayden MJ, James R, Dufty AP, Fox RA, Summers QA, LeSouëf PN (1996) Electrostatic charge on a plastic spacer device influences the delivery of salbutamol. Eur Respir J 9:1943-1946. https://doi.org/10.1183/09031936.96. 09091943

55. Anhøj J, Bisgaard H, Lipworth BJ (1999) Effect of electrostatic charge in plastic spacers on the lung delivery of HFA-salbutamol in children. Br J Clin Pharmacol 47:333-336. https://doi.org/10. 1046/j.1365-2125.1999.00893.x

56. Dompeling E, Oudesluys Murphy AM, Janssens HM et al (2001) Randomised controlled study of clinical efficacy of spacer therapy in asthma with regard to electrostatic charge. Arch Dis Child 84: 178-182. https://doi.org/10.1136/adc.84.2.178

57. Janssens HM, Devadason SG, Hop WCJ et al (1999) Variability of aerosol delivery via spacer devices in young asthmatic children in daily life. Eur Respir J 13:787-791. https://doi.org/10.1034/j.13993003.1999.13d15.x

58. Dubus JC, Guillot C, Badier M (2003) Electrostatic charge on spacer devices and salbutamol response in young children. Int J Pharm 261:159-164. https://doi.org/10.1016/S0378-5173(03)00314-4

59. Hagedoorn P, Bawary W, Frijlink HW, Grasmeijer F (2020) A comparative analysis of changes in pMDI drug dose delivery before and after detergent coating using five antistatic valved holding chambers. J Allergy Clin Immunol Pract 8:1124-1125.e4. https:// doi.org/10.1016/j.jaip.2019.09.021

60. Hatley RHM, von Hollen D, Sandell D, Slator L (2014) In Vitro Characterization of the OptiChamber Diamond Valved Holding Chamber. J Aerosol Med Pulm Drug Deliv 27:S-24-S-36. https:// doi.org/10.1089/jamp.2013.1067

Publisher's note Springer Nature remains neutral with regard to jurisdictional claims in published maps and institutional affiliations. 